\title{
Studies on the Vibrio cholerae mucinase complex. III. Neutralisation of the neuraminidase activity by specific anti-neuraminidase IgG
}

\author{
D.E.S.STEWART-TULL and R.A. OLLAR \\ Department of Microbiology Research Unit, Alexander Stone Building, Garscube Estate, Bearsden, Glasgow \\ G61 1QH
}

\begin{abstract}
Summary. A partially-purified neuraminidase from the mucinase complex of Vibrio cholerae was used to prepare a specific anti-neuraminidase antiserum in rabbits. When the neutralising potency of this serum against $V$. cholerae neuraminidase was assessed in conventional tests, the enzymic activity, as measured by thiobarbituric acid, methoxyphenol-neuraminate and goblet-cell assays, apparently increased. These results are attributable to the presence of a sialylated glycoprotein substrate and small amounts of sialidase in the crude antiserum. However, a twice-purified DEAE-IgG fraction of the antiserum neutralised the enzymic activity of the $V$. cholerae neuraminidase.
\end{abstract}

\section{Introduction}

The mucinase complex of Vibrio cholerae contains neuraminidase, endo- $\beta$ - $\mathrm{N}$-acetylhexosaminidase, nicotinamide-adenine-dinucleotidase and proteinases (Stewart-Tull et al., 1986). These enzymes interact in the breakdown of intestinal mucus and aid the adhesion of $V$. cholerae organisms to the epithelial surface (Schrank and Verwey, 1976; Freter et al., 1978, 1981; Reed and Williams, 1978). The work of Palese et al. (1973) with viral neuraminidase seemed to indicate that it was not neutralised by a specific antiserum because the antibody molecules failed to block the active site of the enzyme. During our search for an acellular cholera vaccine it seemed worthwhile to re-examine the neutralisation of the enzymes of the mucinase complex as a means of preventing colonisation of the intestinal surface.

\section{Materials and methods}

\section{Bacterium}

$V$. cholerae NCTC 10732, the classical biovar, Inaba serovar, was obtained from the National Collection of Type Cultures, Colindale, London.

\section{Production and purification of mucinase complex, estimation of protein and neuraminidase activity}

These procedures were as described by Stewart-Tull et al. (1986).

Received 10 Feb. 1987; revised version accepted 10 May 1987.

\section{Goblet cell assay}

This method was as described by Ollar and StewartTull (1987). The data were analysed statistically by Student's $t$ test (two tailed); the goblet cell counts in the untreated control were compared with those in sections treated with neuraminidase preparations alone or in combination with rabbit normal or immune serum.

\section{Production of $V$. cholerae anti-neuraminidase}

Anti-neuraminidase antiserum DST/R 77 was prepared by immunising rabbits with $1 \mathrm{ml}$ of a mixture containing Sephadex G100/N semi-purified $V$. cholerae neuraminidase $0.5 \mathrm{ml}$, saline $1 \mathrm{ml}$, Bayol F $1.5 \mathrm{ml}$, and Arlacel A $0.6 \mathrm{ml}$. The animals were given an injection of the mixture $(0.5 \mathrm{ml})$ intramuscularly into each hind leg. The mixture for injection into rabbit DST/R78 was similar, but commercial $V$. cholerae neuraminidase (Koch-Light), $100 \mathrm{ImU} / 0.5 \mathrm{ml}$, was used. A booster injection of the appropriate preparation $(2 \mathrm{ml})$ was given intraperitoneally to each rabbit after one month. Ten days later, a blood sample was taken from an ear vein and the serum was tested for the presence of anti-neuraminidase antibodies against the commercial $V$. cholerae neuraminidase by the double diffusion gel test of Ouchterlony (1949). If a positive reaction was observed, animals were killed and exsanguinated by cardiac puncture or by bleeding from the posterior vena cava; the serum was collected and stored at $-20^{\circ} \mathrm{C}$.

Purification of the IgG fraction of $V$. cholerae antineuraminidase antiserum

DEAE cellulose (Whatman, Grade DE 52, anionic exchanger, wet microgranular) was equilibrated with 
$0.01 \mathrm{M}$ phosphate buffer, $p \mathrm{H} \mathrm{7.5.} \mathrm{A} \mathrm{glass} \mathrm{column} \mathrm{(1.5 \times}$ $25 \mathrm{~cm}$ ) was filled with DE 52 slurry and equilibrated with several column volumes of the same buffer. Rabbit antineuraminidase serum (DST/R77 or DST/R78, $4 \mathrm{ml}$ ) was placed in dialysis (Visking) tubing, dialysed overnight at $4^{\circ} \mathrm{C}$ against $0.01 \mathrm{M}$ phosphate buffer, $p \mathrm{H} \mathrm{7.5}$, and applied to the column. The flow-rate of the column was $0.8 \mathrm{ml} /$ min and fractions $(2 \mathrm{ml})$ were collected. The first protein peak eluted with the $0.01 \mathrm{M}$ phosphate buffer contained IgG. The fractions containing IgG were pooled and concentrated with Carbowax to $4 \mathrm{ml}$. This purified IgG fraction was re-chromatographed on DE 52 by a similar procedure.

The IgG was also separated from normal rabbit serum by this method and was used as the negative control preparation.

Neutralisation of $V$. cholerae neuraminidase with rabbit normal or anti-neuraminidase whole sera and their IgG fractions

Rabbit anti-neuraminidase serum (DST/R77 or DST/ R78) or normal serum or the twice-purified IgG fraction from each of these sera $(0.05-0.5 \mathrm{ml}$, as detailed) was mixed with $0.2 \mathrm{ml}$ of one of the $\dot{V}$. cholerae neuraminidase fractions $\left(\mathrm{G} 100 / \mathrm{N}_{2}-\mathrm{G} 100 / \mathrm{N}_{4}\right)$ described by Stewart-Tull et al. (1986), or with Clostridium perfringens neuraminidase. The neuraminidase activity of each of the enzyme preparations added $(0.2 \mathrm{ml})$ was: $\mathrm{G} 100 / \mathrm{N}_{2} 11.0 \mathrm{ImU}$; $\mathrm{G} 100 / \mathrm{N}_{3} 3.99 \mathrm{ImU} ; \mathrm{G} 100 / \mathrm{N}_{4} 5.12 \mathrm{ImU}$; and $C$. perfringens $60.0 \mathrm{ImU}$. The final volume of the neutralisation mixture was adjusted to $0.7 \mathrm{ml}$ by the addition of $0.05 \mathrm{M}$ sodium acetate buffer (NaAc) $p \mathrm{H}$ 5.5. Enzyme plus buffer alone and serum samples plus buffer alone were included as controls. Each mixture was incubated for $2 \mathrm{~h}$ at $37^{\circ} \mathrm{C}$ and left overnight at $4^{\circ} \mathrm{C}$. The mixtures were centrifuged at $1200 \mathrm{~g}$ for $5 \mathrm{~min}$ and the supernates were retained for the studies detailed below.

\section{Studies of the effect of specific anti-neuraminidase antibodies on $V$. cholerae neuraminidase measured by the TBA and MPN assays}

Neuraminidase samples from $V$. cholerae (final concentration in assays: $\mathrm{G} 100 / \mathrm{N}_{2}, 1.57 \mathrm{ImU} ; \mathrm{G} 100 / \mathrm{N}_{3}$, $0.57 \mathrm{ImU} ; \mathrm{G} 100 / \mathrm{N}_{4}, 0.73 \mathrm{ImU}$ ) and $C$. perfringens (Sigma; $4.3 \mathrm{ImU}$ ) treated with whole serum or the IgG of rabbit anti-neuraminidase serum by the procedure described above, were subsequently tested for neuraminidase activity by the thiobarbituric acid (TBA) and methoxyphenol-neuraminate (MPN) assays described by Stewart-Tull et al. (1986). In the TBA assay, controls included neuraminidase plus either DST/R78 antineuraminidase whole serum or its IgG fraction, or normal rabbit serum but without the addition of bovine submaxillary mucin, in order to check for the possible addition of sialic acid from the serum. In addition, (i) neuramini-

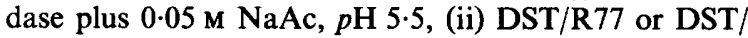
R78 plus $\mathrm{NaAc}$, (iii) IgG fractions from these sera plus
$\mathrm{NaAc}$, and (iv) normal serum plus $\mathrm{NaAc}$ were included as controls in both assays.

Samples $(0.2 \mathrm{ml})$ of the treated neuraminidase preparations (final concentration $V$. cholerae $\mathrm{G} 100 / \mathrm{N}_{2}$, $3.4 \mathrm{ImU} ; \mathrm{Gl00} / \mathrm{N}_{3}, 1.14 \mathrm{ImU} ; \mathrm{G} 100 / \mathrm{N}_{4}, 1.46 \mathrm{ImU}$ and C. perfringens $8.6 \mathrm{ImU}$ ) were pipetted on to rat ileal tissue sections, $8 \mu \mathrm{m}$ thick on glass microscope slides, cut in a cryostat, as described by Ollar and Stewart-Tull (1987). The sections covered with a neuraminidase sample were incubated in a moist chamber at $37^{\circ} \mathrm{C}$ for $24 \mathrm{~h}$. Subsequently, the sections were stained by the Alcian blue/ PAS procedure (Mowry and Winkler, 1956) and histochemical changes in the mucin were measured by the goblet-cell assay (Ollar and Stewart-Tull, 1987).

\section{Results}

\section{Neutralisation of neuraminidase activity by rabbit anti-neuraminidase sera DST/R77 and DST/R78}

The neutralisation of partially-purified $V$. cholerae neuraminidase preparations (G100/N2, 1.57 ImU; G100/N3, 0.57 ImU; G100/N4, $0.73 \mathrm{ImU})$ with rabbit anti-V. cholerae neuraminidase serum DST/R77 (0.05-0.3 ml) caused a reduction in the amount of $\mathrm{N}$-acetyl neuraminic acid (NANA) released from bovine submaxillary mucin by the enzyme, as measured by the TBA assay. Maximum enzyme neutralisation was obtained with $0.3 \mathrm{ml}$ of the $V$. cholerae antiserum. However, when further amounts of this serum (0.35-0.5 ml) were added to these neuraminidase preparations, the effect appeared to be reversed (table).

In addition, the neuraminidase preparations released a TBA-reactive substance, possibly NANA, from the serum DST/R77 $(0.5 \mathrm{ml})$ in a

Table. The effect of neutralising $V$. cholerae neuraminidase preparations with specific antiserum DST/R77

$\mathrm{N}$-acetyl neuraminic acid (NANA) released

$(\mu \mathrm{g})$ from bovine submaxillary mucin in TBA assay by $V$. cholerae preparation $(0.2 \mathrm{ml})$ mixed with the stated amount of antiserum

\begin{tabular}{cccc} 
Amount of & & & \\
\cline { 2 - 4 } antiserum & $\mathrm{G} 100 / \mathrm{N}_{2}$ & $\mathrm{G} 100 / \mathrm{N}_{3}$ & $\mathrm{G} 100 / \mathrm{N}_{4}$ \\
added $(\mathrm{ml})$ & $1.57 \mathrm{ImU}$ & $0.57 \mathrm{ImU}$ & $0.73 \mathrm{ImU}$
\end{tabular}

\begin{tabular}{llll}
\hline $0^{*}$ & $3.60 \dagger$ & $0 \cdot 25$ & $3 \cdot 0$ \\
$0 \cdot 3$ & 0 & 0 & 1.25 \\
0.4 & 1.50 & $0 \cdot 25$ & $1 \cdot 50$ \\
0.5 & 1.50 & 0.50 & $2 \cdot 50$ \\
\hline
\end{tabular}

* The final volume in each neutralisation mixture was adjusted to $0.7 \mathrm{ml}$ with $0.05 \mathrm{M}$ sodium acetate buffer, $p \mathrm{H} 5.5$.

$\dagger$ All values were corrected for the release of NANA, (i) from serum in the absence of mucin, and (ii) from mucin by serum in the absence of enzyme. 
control mixture without bovine submaxillary mucin $\left(\mathrm{G} 100 / \mathrm{N}_{2} \quad 1.25 \mu \mathrm{g}, \mathrm{G} 100 / \mathrm{N}_{3} 0.5 \mu \mathrm{g}, \mathrm{G} 100 / \mathrm{N}_{4}\right.$ $1.85 \mu \mathrm{g})$. The same serum DST/R77 appeared to add a small amount $(0.5 \mu \mathrm{g})$ of TBA-reactive substance as revealed by the control test to which neuraminidase was not added.

To check whether the neuraminidases released NANA from the antiserum DST/R77, these experiments were repeated with the substrate-specific MPN assay. As the amount of antiserum was increased from $0.3 \mathrm{ml}$ to $0.5 \mathrm{ml}$, surprisingly, there was a corresponding increase in the amount of methoxyphenol liberated ( 78 to 118 nmoles).

After these initial experiments it was decided to purify the IgG fraction of normal and antineuraminidase rabbit serum. In the TBA assay the specific rabbit anti- $V$. cholerae neuraminidase serum DST/R78 (0.05-0.2 ml) reduced the activity of the $\mathrm{G} 100 / \mathrm{N}_{2}$ neuraminidase when compared with the untreated enzyme preparation (fig. 1a). Normal rabbit serum did not neutralise neuraminidase activity but, on the contrary, accentuated it (fig. 1b). However, with the twice-purified specific anti- $V$. cholerae neuraminidase $\mathrm{IgG}, 0.05-0.2 \mathrm{ml}$, complete neutralisation of the neuraminidase occurred; normal serum IgG neither neutralised nor enhanced the neuraminidase activity (fig. 1).

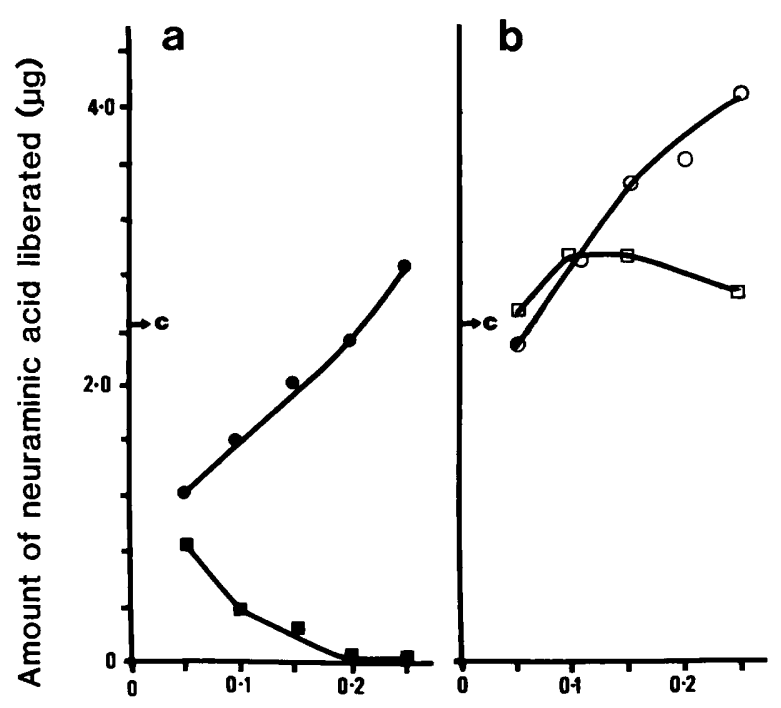

IgG preparation or serum added (ml)

Fig. 1. Neutralisation of $V$. cholerae neuraminidase $\mathrm{GlO0/N} / \mathrm{N}_{2}$ as measured in the thiobarbituric acid assay. The activity of G100/ $\mathrm{N}_{2}$, (a) absorbed with the whole serum (-O) or the $\mathrm{IgG}$ fraction ( $\square$ ) of rabbit anti-neuraminidase serum DST/R78; and (b), absorbed with the non-immune rabbit whole serum $(\mathrm{O}-\mathrm{O})$ or its IgG fraction $(\square-\square)$ is shown, compared with (C) the level of enzymic activity before treatment.
Results with the more sensitive MPN assay indicated that the specific rabbit anti- $V$. cholerae neuraminidase serum DST/R78 did not neutralise enzymic activity but accentuated it in a manner similar to that found with normal serum (figs. 2a,b). The twice-purified IgG fraction of this antiserum DST/R78 significantly reduced the level of neuraminidase activity, whereas the twice purified IgG fraction of normal serum did not (figs. 2a,b).

\section{The effect of specific immunoglobulins on the} neutralisation of $V$. cholerae neuraminidase activity in ileal tissue sections

An examination of rat ileal tissue sections in the goblet-cell assay showed a significant difference ( $p<0.02$; with 38 degrees of freedom in all tests) between the number of goblet cells stained with Alcian blue in untreated sections or those treated with the $V$. cholerae $\mathrm{G} 100 / \mathrm{N}_{2}$ neuraminidase preparation $\left(1.57 \mathrm{ImU}\right.$ in assay) alone $\left(477 / \mathrm{cm}^{2}\right.$ field area) or in combination with $0.1 \mathrm{ml}$ of normal rabbit serum $\left(353 / \mathrm{cm}^{2}\right)$. However, as the amount of normal rabbit serum was increased, to a maximum of $0.4 \mathrm{ml}$, there was a significant decrease in alcianophilia in the goblet cells $(p<0.0002)$ and concomitantly a significant increase in the number of magenta-stained, PAS-positive goblet cells $(p<0.0002)$. For example, when the $G 100 / N_{2}$ preparation, in combination with normal rabbit serum, $0.4 \mathrm{ml}$, was used to treat a rat ileal section, the alcianophilia decreased from $477 / \mathrm{cm}^{2}$ field area in the untreated section to $230 / \mathrm{cm}^{2}(\mathrm{p}<0.0002)$. Similarly, the numbers of magenta PAS-stained cells were $98 / \mathrm{cm}^{2}$ in the untreated and $244 / \mathrm{cm}^{2}$ in the treated section $(\mathrm{p}<0.0002)$.

Subsequent experiments were done with the rabbit anti-neuraminidase whole serum DST/R78 and its twice-purified IgG. Fig. 3 shows that a similar decrease was observed in the number of alcianophilic goblet cells after treatment of rat ileal sections with the G100/ $\mathrm{N}_{2} V$. cholerae neuraminidase $\left(262 / \mathrm{cm}^{2} ; \mathrm{p}<0.001\right)$ and an even greater decrease after treatment with $\mathrm{G} 100 / \mathrm{N}_{2}$ neuraminidase plus anti-neuraminidase serum $\left(183 / \mathrm{cm}^{2}\right.$; $\mathrm{p}<0.0002)$. In addition, there was a significant decrease in the number of alcianophilic goblet cells in control sections treated with a similar amount of anti-neuraminidase serum alone $\left(218 / \mathrm{cm}^{2} ; \mathrm{p}<\right.$ $0.001)$. In all instances there was an associated increase in the number of magenta-stained goblet cells $\left(308 / \mathrm{cm}^{2}, \mathrm{p}<0.0002 ; 529 / \mathrm{cm}^{2}, \mathrm{p}<0.0002\right.$; $485 / \mathrm{cm}^{2}, \mathrm{p}<0.0002$ respectively).

In contrast, when the DEAE twice-purified antineuraminidase IgG preparation was used in a 


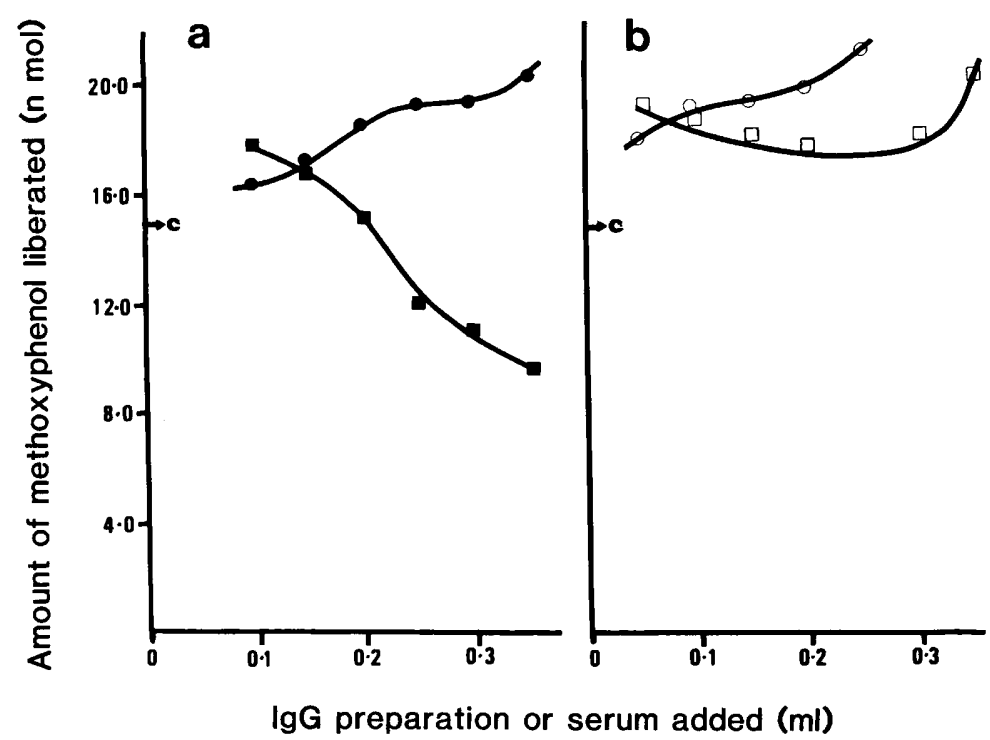

Fig. 2. Neutralisation of $V$. cholerae neuraminidase $\mathrm{G} 100 / \mathrm{N}_{2}$ as measured by the methoxyphenol-neuraminate assay. The activity of $\mathrm{G} 100 / \mathrm{N}_{2}$, (a) absorbed with the whole serum (-O) or the IgG fraction ( $\left.-\square\right)$ of rabbit anti-neuraminidase serum DST/ R78; and (b), absorbed with the non-immune rabbit whole serum (O-O) or its IgG fraction ( $\square-\square$ ) is shown, compared with (C) the level of enzymic activity before treatment.

comparable series of tests the number of alcianophilic cells in the untreated control preparations was $445 / \mathrm{cm}^{2}$ field area and there was no significant decrease in those treated with either the $\mathrm{G} 100 / \mathrm{N}_{2}$ neuraminidase plus specific IgG $\left(428 / \mathrm{cm}^{2} ; \mathrm{p}>0.8\right)$ or with the specific anti-neuraminidase IgG alone $\left(409 / \mathrm{cm}^{2} ; \mathrm{p}>0.95\right)$.

\section{Discussion}

As part of a broad study to isolate and characterise possible protective antigens of $V$. cholerae suitable for use in an acellular vaccine it was important to know whether the neuraminidase was functionally and antigenically distinct from mammalian neuraminidase and also whether it was immunogenic in the mammalian host.

In higher vertebrates, neuraminidases (sialidases) are associated with lysosomes and other cell organelles. Mammalian neuraminidases may remove sialic acid residues and thus regulate the amount of glycoprotein circulating in serum (Hutchinson and Kabayo, 1977). The sialic acid residue protects the serum glycoprotein from catabolism but neuraminidase exposes a terminal galactose residue which can bind to a galactosespecific lectin on hepatocytes, the first step in the degradation process (Ashwell and Morell, 1974). The result of our study indicates that partially purified cholera neuraminidase preparations are able to release small quantities of TBA-reactive substances from rabbit serum glycoprotein. However, it seems that the removal of neuraminic acid residues from serum glycoproteins is unlikely to be a major factor in the pathogenesis of cholera as, in general, the plasma protein concentration in cholera is greatly increased by the loss of fluid and electrolytes.

Ramphal and Pyle (1983) noted that the activity of neuraminidases on neuraminic acid-containing glycoproteins depended upon the source of the enzyme. This was examined previously by Finne (1978) with the neuraminidases from $V$. cholerae and $C$. perfringens. The $V$. cholerae enzyme cleaved neuraminic acid from follicle stimulating hormone (FSH) but did not act on luteinising hormone (LH). In contrast, $C$. perfringens enzyme acted on FSH and LH. Whether this substrate specificity might be due to the presence of different antigenic determinants in the enzymes from these two bacteria was a point for consideration.

In our study, both the $V$. cholerae partiallypurified neuraminidase and rabbit serum neuraminidase released free methoxyphenol in the substratespecific MPN assay. It would follow from Finné (1978) that these neuraminidases share common antigenic determinants. Consequently, there was an initial doubt about the ability of the $V$. cholerae 


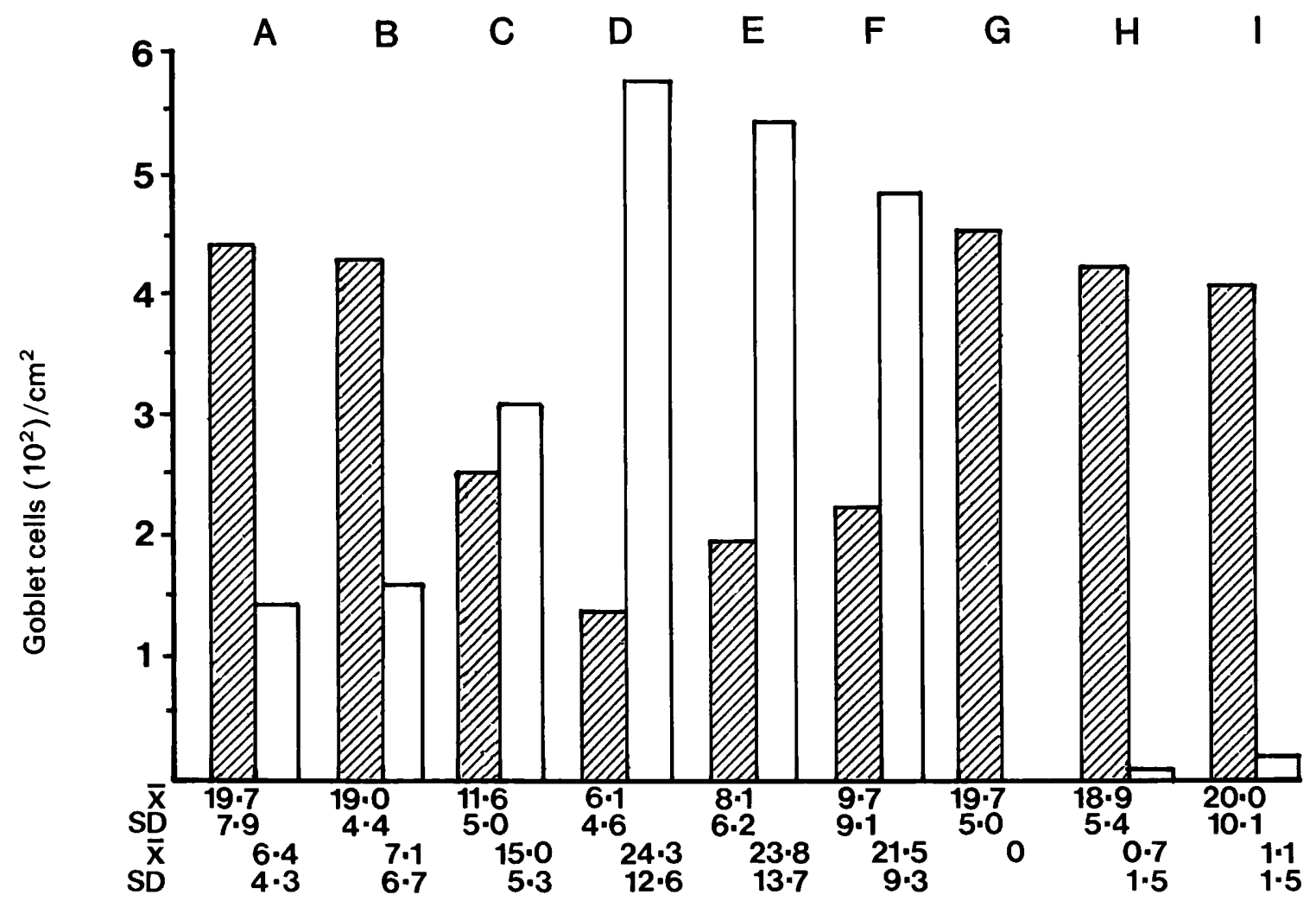

Fig. 3. The effect of specific anti-neuraminidase whole serum or the IgG fraction (DST/R78) on the neutralisation of a neuraminidaseinduced reduction in alcianophilia in goblet cells. (A) Untreated section; or sections treated with (B) sodium acetate buffer, $p \mathrm{H} 5 \cdot 0$; (C) G100/ $\mathrm{N}_{2}$ V. cholerae neuraminidase (1.57 ImU in assay); (D) G100/ $\mathrm{N}_{2}(1.57 \mathrm{ImU}$ in assay) + whole anti-neuraminidase serum $(0.05 \mathrm{ml}) ;(\mathbf{E}) \mathrm{G100} / \mathrm{N}_{2}(1.57 \mathrm{ImU}$ in assay) + whole anti-neuraminidase serum $(0.25 \mathrm{ml})$; (F) anti-neuraminidase serum control $(0.25 \mathrm{ml}) ;(\mathrm{G}) \mathrm{G} 100 / \mathrm{N}_{2}\left(1.57 \mathrm{ImU}\right.$ in assay) + IgG anti-neuraminidase $(0.05 \mathrm{ml}) ;(\mathrm{H}) \mathrm{G} 100 / \mathrm{N}_{2}(1.57 \mathrm{ImU}$ in assay) + IgG antineuraminidase $(0.25 \mathrm{ml})$; (I) serum control of IgG anti-neuraminidase $(0.25 \mathrm{ml})$. The solid columns represent the number of normal alcianophilic goblet cells (purple stained) and the open columns the number of goblet cells containing neutral mucosubstances after neuraminidase treatment (magenta-staining).

Note that the cells are over-distributed in many instances $(\mathrm{SD}>\sqrt{\overline{\mathbf{x}}})$ which reflects the distribution of goblet cells within random fields (see Wardlaw, 1985).

neuraminidase to elicit an immune response in the rabbit. The results presented here reveal that substrate specificity is not correlated with antigenic specificity as it was possible to raise anti- $V$. cholerae neuraminidase antibodies in rabbits.

Palese et al. (1973) produced evidence that although viral neuraminidases stimulated the production of antibodies in rabbits, these antisera did not neutralise enzyme action as measured by the MPN assay. In our initial experiments, rabbit $V$. cholerae anti-neuraminidase DST/R 77 serum neutralised $V$. cholerae activity by $58 \%$ and $C$. perfringens activity by $70 \%$, which also indicated a considerable antigenic similarity between the neuraminidases from these two organisms. However, as the amount of whole serum, used to neutralise the enzyme, was increased, there appeared to be an associated increase in enzyme activity. This might be associated with a sialylated serum glycoprotein or a serum neuraminidase, or both, as discussed above. The greater increase in the amount of NANA released in the less substrate-specific TBA than methoxyphenol in the specific MPN assay suggests that the apparent increase in activity was due to the addition of extra substrate from the serum. Nevertheless, the results from the gobletcell assay clearly indicate the presence of a serum neuraminidase in the rabbit anti-neuraminidase DST/R78 serum since there was a great reduction in the observed alcianophilia in the goblet cells of ileal sections treated with this serum. The values obtained in the TBA and MPN assays with whole serum, therefore, represent the net result of enzyme neutralisation and additional enzyme activity. 
These findings explain the lack of neutralisation observed by Palese et al. (1973). After purification twice by DEAE chromatography, the IgG fraction of the rabbit anti-neuraminidase serum neutralised the activity of the enzyme, but lacked any neuraminidase activity itself. It could also be argued from the results that the rabbit anti- $V$. cholerae neuraminidase could contain antibodies against an enzyme inhibitor present in the partially-purified $V$. cholerae neuraminidase preparations used to raise the antiserum. If such an inhibitor was precipitated with antibody, the specific neuraminidase activity would increase. Furthermore, the

\section{REFERENCES}

Ashwell G, Morell A G 1974 The role of surface carbohydrates in the hepatic recognition and transport of circulating glycoproteins. Advances in Enzymology 41 : 99-128.

Finné E 1978 Specificity of action of neuraminidase according to its bacteriological origin Endokrinologie 72: 363-364.

Freter R, Allweiss B, O'Brien P C M, Halstead S A, Macsai M S 1981 Role of chemotaxis in the association of motile bacteria with intestinal mucosa: in-vitro studies. Infection and Immunity 34: 241-249.

Freter R, O'Brien P C M, Halstead S A 1978 Adhesion and chemotaxis as determinants of bacterial association with mucosal surfaces. In: McGhee J R et al. (eds) Secretory immune system and caries immunity (Advances in experimental medicine and biology, vol. 107) Plenum Press, New York, pp 429-437.

Hutchinson D W, Kabayo J P 1977 Current thoughts on neuraminidase. Trends in Biochemical Sciences 2: 1-3.

Mowry R W, Winkler C H 1956 The coloration of acidic carbohydrates of bacteria and fungi in tissue sections with special reference to capsules of Cryptococcus neoformans, Pneumococci and Staphylococci. American Journal of Pathology 32: 628-629.

Ollar R A, Stewart-Tull D E S 1987 Studies on the Vibrio cholerae binding of the antibody to the $V$. cholerae neuraminidase might induce the activation of a proenzyme and cause an increase in activity. The experiments with the twice-purified IgG of rabbit anti-neuraminidase serum would disprove both possibilities because the neuraminidase was neutralised. The neuraminidase complex plays an important role in the breakdown of the intestinal sialomucin enabling the organism to colonise the epithelial surface and to release its enterotoxin (Stewart-Tull et al., 1986). It remains to be shown whether anti- $V$. cholerae neuraminidase antibodies can protect against an infection with $V$. cholerae.

mucinase complex. II. Specific neuraminidase activity measured histochemically in a goblet cell assay. Journal of Medical Microbiology 23: 227-232.

Ouchterlony O 1949 Antigen-antibody reactions in gels. Acta Pathologica et Microbiologica Scandinavica 26: 507-515.

Palese P, Bucher D, Kilbourne E D 1973 Applications of a synthetic neuraminidase substrate. Applied Microbiology 25: 195-201.

Ramphal R, Pyle M 1983 Adherence of mucoid and nonmucoid Pseudomonas aeruginosa to acid-injured tracheal epithelium. Infection and Immunity 41 : 345-351.

Reed W P, Williams R C 1978 Bacterial adherence: first step in the pathogenesis of certain infections. Journal of Chronic Diseases 31 : 67-72.

Schrank G D, Verwey W F 1976 Distribution of cholera organisms in experimental Vibrio cholerae infections: proposed mechanisms of pathogenesis and antibacterial immunity. Infection and Immunity 13: 195-203.

Stewart-Tull D E S, Ollar R A, Scobie T S 1986 Studies on the Vibrio cholerae mucinase complex. I. Enzymic activities associated with the complex. Journal of Medical Microbiology 22: 325-333.

Wardlaw A C 1985 Practical statistics for experimental biologists. John Wiley \& Sons, Chichester, pp 134-136. 